Maurer School of Law: Indiana University

Digital Repository @ Maurer Law

1979

\title{
Joint Ventures and the Justice Department's Antitrust Guide for International Operations
}

Joseph F. Brodley

Indiana University School of Law

Follow this and additional works at: https://www.repository.law.indiana.edu/facpub

Part of the Antitrust and Trade Regulation Commons, and the International Trade Law Commons

\section{Recommended Citation}

Brodley, Joseph F., "Joint Ventures and the Justice Department's Antitrust Guide for International Operations" (1979). Articles by Maurer Faculty. 1719.

https://www.repository.law.indiana.edu/facpub/1719

This Article is brought to you for free and open access by the Faculty Scholarship at Digital Repository @ Maurer Law. It has been accepted for inclusion in Articles by Maurer Faculty by an authorized administrator of Digital Repository @ Maurer Law. For more information, please contact rvaughan@indiana.edu. 


\title{
JOINT VENTURES AND THE JUSTICE DEPARTMENT'S ANTITRUST GUIDE FOR INTERNATIONAL OPERATIONS
}

\author{
by
}

JOSEPH F. BRODLEY*

Writing in this journal in 1976 I described the law of joint ventures as "one of the darkest corners of antitrust" - a situation caused in no small part by the absence of recent antitrust precedents. Penetrating the darkness, the Antitrust Guide for International Operations ${ }^{2}$ is a welcome addition to antitrust jurisprudence, since almost a third of its specific substantive discussion involves joint ventures. To be sure, the discussion focuses on joint ventures in international trade, where special problems exist not replicated in domestic markets, ${ }^{3}$ and much of the discussion concerns the legality of collateral agreements rather than joint ventures as such. Nevertheless, the analysis of joint ventures has relevance not confined to international markets or embedded collateral agreements, and hence what the Antitrust Guide has to say provides added illumination in a difficult area." Moreover, since the Antitrust Guide is a

* Professor of Law, Indiana University (Bloomington).

1 Brodley, The Legal Status of Joint Ventures Under the Antitrust Laws: A Summary Assessment, 21 ANTITRUST BULL. 453 (1976) (hereafter cited as Brodley, Joint Ventures).

2 Antitrust Division U.S. Depart. of Justice, Antitrust Guidf rok International Operations (1977) (hereafter referred to as Antitrust Guide), reprinted in Trade Reg. ReP. (CCH) No. 266, Pt. II (1977). (Citations are to the $\mathrm{CCH}$ reprint.)

3 E.g., antitrust jurisdiction over foreign commerce, comity, Act of State doctrine, Webb-Pomerene Act and international agreements between governments.

- This has been made explicit by a policy spokesman for the Antitrust Division, who states that much of the legal analysis, including that directly applicable to at least two of the specific cases discussed (Cases C and D), is "essentially identical to that which would apply

(C) 1979 by Federal Legal Publications, Inc. 
statement of enforcement policy, it can be useful in assessing the outer boundaries of possible governmental challenge, for surely a joint venture which is questionable in the possibly less hostile environment of international trade would be at least equally suspect if it occurred solely in domestic markets.

In my previous article on joint ventures I concluded that the classification of a joint venture with respect to the parents' market, as horizontal, vertical or conglomerate, was of explanatory importance. More specifically, as between parents with high market shares who are competitors or potential competitors in concentrated markets-(1) a horizontal joint venture was inevitably suspect; (2) a market extension joint venture organized on a permanent basis was equally suspect where the parents together held a dominant market position; (3) a vertical joint venture involving the marketing of a product produced by both parents was also questionable (although the legal authority for this conclusion was sparse); and (4) a pure conglomerate or pure product extension joint venture was unlikely to raise antitrust problems under existing precedents. ${ }^{5}$ As between high market share parents, this left as the areas of greatest legal doubt (1) limited term market extensions; (2) market extensions as to one parent only; and (3) upstream vertical joint ventures. ${ }^{6}$ Strikingly, it is precisely on these areas that the Antitrust Guide focuses.

in a domestic antitrust case." Donald A. Farmer, Jr., remarks before a seminar sponsored by the Council of the Americas in Cleveland, Ohio (June 8, 1977), reprinted in 5 TRADE REG. REP. (CCH) 950,325, at 55,689. See also Ky P. Ewing, Jr., Antitrust Enforcement: A Positive Force for Innovation, remarks before Institute of Electrical and Electronic Engineers, at Arlington, Virginia (Sept. 20, 1978) at pp. 8-9.

5 Brodley, Joint Ventures, supra note 1, at 456-472.

6 Id. at $467-468 ; 477-478$. 
The core antitrust doctrine applied in the Antitrust Guide is the rule of reason, and this in itself invites close attention in view of the increased emphasis placed on the rule in recent Supreme Court decisions. ${ }^{7}$ Reliance on the rule of reason, moreover, sharply differentiates the Antitrust Guide from the 1968 Merger Guidelines, which rested extensively on presumptive rules. In place of such explicit rules, the Antitrust Guide has substituted a series of short factual scenarios, called "cases," followed by brief, often conclusory, comment. ${ }^{8}$

What general rules the Antitrust Guide does articulate are stated in such general terms as to give little legal guidance. Thus, the core doctrine of the rule of reason is phrased in broad language, which while familiar to readers, will scarcely resolve hard cases. The Guide's articulation of the rule touches the familiar bases of whether the alleged anticompetitive restraint is "ancillary to a lawful main purpose," whether its scope and duration are no greater then necessary to achieve

7 See, Continental T.V. Inc. v. GTE Sylvania, Inc., 433 U.S. 36 (1977) and National Soc'y. of Professional Engineers v. United States, 98 S.Ct. 1355 (1978).

8 The term "cases" perhaps claims too much, for while the transactions described in the Guide are based on actual occurrences (see Seki, The Justice Department's New Antitrust Guide for International Operations-A Summary and Evaluation, 32 BuS. LAWYER 1633 (1977)), the facts are simplified and incomplete, and the comment is frequently hedged. Perhaps for this reason there is a sterility and lifelessness in the cases, a one-dimensionality caused by the loss of contextual depth.

For a good general assessment of the impact of the Antitrust Guide on antitrust enforcement in international trade see Fugate, The Department of Justice's Antitrust Guide for International Operations, 17 VA. J. INT'L L. 645 (1977) (hereafter cited as Fugate, Antitrust Guide). See also Douglas E. Rosenthal, Remarks to the Antitrust and Trade Regulation Committee, U.S. Chamber of Commerce (March 9, 1977), reprinted in 5 TRADE REg. REP. (CCH) 950,309; Griffin, A Critique of the Justice Department's Antitrust Guide for International Operations, 11 CORNELL INT'L L.J. 215 (1978); and Baker, Critique of the Antitrust Guide: A Rejoinder, 11 CoRnELL INT'L. L.J. 255 (1978). 
that purpose, and whether the restriction is otherwise reasonable in light of all relevant facts and circumstances. ${ }^{9}$

The Department's enforcement policies are not, however, revealed in such general formulations, but rather in the discussion of the specific cases, of which four involve joint ventures. ${ }^{10}$ The cases involve joint ventures between competitors or potential competitors ${ }^{11}$ in concentrated markets, engaging in either limited term market extensions, unlimited term partial market extensions or upstream vertical joint ventures. These will be discussed in turn.

\section{Limited Term Market Extensions}

In a market extension joint venture, parents engaged in the same product line form a joint venture to enter a new geographic market. Market extension joint ventures between major producers holding large market shares have been successfully challenged in prior joint venture decisions on essentially two theories: (1) injury to potential competition through

- Antitrust Guide, supra note 2, at 3-4. This articulation follows closely McLaren, The Licensing of Technology Under the United States Antitrust Laws, 40 ANTITRust L.J. 931, 936 (1971) (which the Guide expressly cites on the point).

10 Joint ventures comprise only four of the 14 cases discussed, which cover a wide variety of arrangements between firms in international trade (including multinational affiliates, foreign acquisitions and mergers, patent and technology licensing, and joint action involving foreign governments).

11 Enforcement emphasis on joint ventures between competitive firms is consistent with treatments by commentators. See K. BREWSter, ANTITRust and American Business Abroad 200-223 (1958) (discussion of joint ventures confined to those between competitors or potential competitors); and see 3 AREEDA \& TURNER, ANTITRUST LAW 113-114 (1978) (preliminary discussion of problems in joint ventures between competitors and potential competitors). See also Antitrust Guide, supra note 2, at 20 (care advised in policing operations of joint ventures between competitors and potential competitors). 
loss of the parents as potential entrants into the joint venture market and (2) increased probability of collusion between the parents in their home market, facilitated by the joint venture. ${ }^{12}$ The decided cases have involved permanent joint ventures between parents individually capable of market entry. The question posed in the Guide's hypothetical case is whether a more lenient rule applies if the joint venture is limited in its term of existence and if the parents are not capable of individual market entry?

In Case $\mathrm{C}$ the joint venture is a joint bidding consortium involving a single project, and made up of firms, several of them competing, drawn from three industries. The venture is both limited in time and necessary for market entry. Formed to undertake a large hydroelectric project in Latin America, the consortium includes three of the six largest electrical equipment manufacturers, three of the eight largest engineering firms, and one of only two hydroelectric generator manufacturers.

The antitrust issues are (1) whether creation of the joint venture restrained competition, (2) whether collateral agreements are present that in themselves are unreasonably restrictive, and (3) whether the joint venture involves a "bottleneck" foreclosure problem. The Antitrust Guide concludes that formation of the joint venture was economically necessary because a smaller group would have lacked financial and technical capability and perhaps would have been unwilling to assume the political risk. Under these circumstances and given the limited purpose and duration of the joint venture, the Department would almost surely view the joint venture as justi-

12 See Brodley, Joint Ventures, supra note 1, at 459-461.

Both theories have been criticized as unsound in application to joint ventures. See R. Posner, Antitrust Law: An Economic PerspecTIVE 115-116 (1976) (potential competition injury) and Whipple, Problems of Combination-Integration, Intra-Corporate Conspiracy and Joint Ventures, 1958 AntrTRuST LaW Symposium (N.Y. State Bar Ass'n.) 34, 53 (CCH 1958) (spillover collusion). The Antitrust Guide (properly) does not assume the task of reevaluating the wisdom of the behavioral premises of existing joint venture law. 
fied even had its operations been entirely domestic. ${ }^{13}$ Legality becomes clearer still where, as in Case $\mathrm{C}$, the consortium involves purely foreign operations because "normally" the Department will not challenge a joint venture which at most reduces competition in a foreign market; for such a case involves no injury to either consumers or producers within the United States. ${ }^{14}$

Under the Guide's analysis the only appreciable antitrust risks, therefore, are spillover collusion and bottleneck exclusion. Spillover collusion between the parents into other areas of their operations must be considered since several of the parents are competitors. To reduce the risk of spillover collusion, the Guide advises firms to "use special care in policing the operation of a joint venture involving actual or potential

13 It should be noted that none of the parents was the largest firm in its industry (a characteristic also present in the other joint venture cases discussed in the Guide). This might be interpreted as leaving open the possibility that the Guide would operate more stringently against a joint venture that includes the ranking firm in a concentrated marked. Mitigating this restrictive interpretation is the fact that the actual transaction from which Case $C$ was drawn involved Antitrust Division approval of a consortium that included the largest firm in an important industry. See Douglas E. Rosenthal, Remarks on the Antitrust Guide for International Operations, ABA Sections on International Law and Patent, Trademark and Copyright Law, in New York City, at p. 3 (Aug. 9, 1978).

14 Antitrust Guide, supra note 2, at 21. The Guide further points out that since the joint venture may not be engaged in commerce, Section 7 of the Clayton Act "frequently does not apply," although Section 1 of the Sherman Act remains applicable under the broader "affecting commerce" standard. Id.

It should be noted that formation of the joint venture in Case $\mathrm{C}$, despite its foreign situs, would be subject to the premerger notification requirements of the Clayton Act. 15 U.S.C. \$18a. Notification is required when inter alia the acquiring person is engaged in commerce (or its activities affect commerce). Ibid. Here the parents are the acquiring persons and are clearly engaged in commerce. Applicability of the premerger notification requirements to joint ventures is made explicit in the FTC's Premerger Notification Rules. See Trade REg. ReP. (CCH) No. 320 (Feb. 16, 1978) §801.40. 
competitors." ${ }^{15}$ Indeed, where a joint venture is long-lasting, it may even be advisable to staff the joint venture with separate personnel to reduce day-to-day contact between the parents. ${ }^{16}$ A joint venture may also transgress the antitrust laws if it has "bottleneck" properties, i.e., if it forecloses competitors from an essential facility or requirement. A limited term consortium would, however, rarely, if ever, pose such a problem; in fact, the Department knew of no application of the bottleneck doctrine to a short term consortium. ${ }^{17}$

The Guide's analysis clarifies to some degree an area marked by absence of legal precedent, and one increasingly important in high technology and large capital projects, both within and without the United States. The discussion suggests that limited term, single project joint ventures will generally be permitted, and most certainly in foreign markets, where (1) the joint ventures includes substantially less than all firms within an industry, (2) the project is beyond the capability of any single parent or smaller subset of parents, ${ }^{18}(3)$ duration of the joint venture is limited to the life of the project that called it forth, and (4) some positive efforts are taken to structure the management and day-to-day operations of the joint

15 Antitrust Guide, supra note 2, at 20.

16 Id.

17 Id. at 21-22. In its discussion of a subsequent case, however, the Guide appears to treat the bottleneck doctrine as applicable to a limited term joint venture. See Antitrust Guide at 58-61 (Case M) and infra notes 41-45 and related text. Moreover, even in the discussion of Case $\mathrm{C}$ the Guide finds it necessary to discount the possibility that the joint venture had bottleneck properties as to non-in. cluded firms (suggesting that if competitors of the parents wished to participate in the bidding they might form a competitive consortium).

18 Lack of capability appears to be interpreted broadly in the Guide to include not only absence of technological capability, but also lack of financial capability, and ability to achieve scale economies and risk spreading. See generally, Antitrust Guide, supra note 2, at 19-21. One suspects, however, that lack of capability may be viewed more expansively in foreign than in domestic markets. 
venture to minimize risks of spillover collusion between parents who are themselves competitors.

\section{UnLimited Term Market Exténsions}

An unlimited term market extension joint venture between large, competitive firms in concentrated markets is apt to raise more serious antitrust questions. Particularly is this so when the joint venture amounts to a market extension as to both parents, for then, as we have seen, the precedents have identified both potential competition and collusion spillover risks. ${ }^{19}$ When, however, the joint venture is a market extension as to one parent only, antitrust analysis is less well articulated; and it is this problem which the Antitrust Guide discusses.

Case $\mathrm{E}$ involves a joint venture to manufacture transistors in Japan formed by a U.S. based manufacturer of transistors and a Japanese-based manufacturer of other types of electronic equipment. Thus, the joint venture is a market extension as to the U.S. parent and a product extension as to the Japanese parent. Each of the parents would have faced substantial entry barriers in attempting individually to enter the Japanese transistor market: the U.S. parent had high costs and the Japanese parent lacked production know-how. Under these circumstances formation of the joint venture appeared to be a business necessity for both parents, notwithstanding the fact that the U.S. parent was the third ranking firm, holding $22 \%$ of a highly concentrated domestic transistor market, and the Japanese parent was one of that country's "largest industrial combines." ${ }^{20}$ The plan was that the joint venture would manufacture transistors in Japan, using the U.S. parent's technical know-how and the Japanese parent's knowledge of the local market. Because the joint venture's manufacturing costs would be below those of its U.S. parent,

19 See, supra, text at note 12.

${ }^{20}$ Antitrust Guide, supra note 2, at 28. 
the latter also insisted on a collateral agreement that neither the joint venture nor the other (Japanese) parent would export transistors to the United States or to certain designated foreign markets presently being served by the U.S. parent.

Under the Antitrust Guide's analysis, formation of the joint venture, as distinct from the collateral agreement, would not in itself violate the antitrust laws. There is no injury to existing competition since the parents are not competitors, and the joint venture does not appear to be part of any broader anticompetitive arrangement. While formation of the joint venture could arguably injure potential competition under Section 7 of the Clayton Act, considering the Japanese parent's potential to enter the United States transistor market, such a theory would face at least two severe difficulties as applied to an international transaction. Section 7 may be inapplicable since it is unclear that the acquired firm (the joint venture) is engaged in commerce, as required by the statute. $^{21}$ Moreover, if there are other large or significant foreign firms presently producing transistors, the Japanese parent may not qualify as one of the few most probable market entrants into the United States market. ${ }^{22}$

A more serious antitrust problem is presented by the collateral agreement protecting the U.S. parent's present transistor markets, domestic and foreign, from competition by either the Japanese parent or the joint venture. These restrictions constitute an express division of geographic markets, including the United States domestic market, and can be

\footnotetext{
21 See note 14 supra.

${ }^{22}$ Antitrust Guide, supra note 2, at 28-29. In addition, if Section 7 of the Clayton Act is inapplicable for jurisdictional reasons, it seems unlikely that a joint venture which would at most foreclose potential market entry by only one parent would be held unlawful under the Sherman Act. Indeed, the potential competition doctrine as applied to single firm market entry has caused the government difficulties enough even under the more flexible standards of the Clayton Act. See generally, Brodley, Potential Competition Mergers: A Structural Syntheses, 87 YaLE L.J. 1 (1977).
} 
justified only as necessary to assure formation of the joint venture. Arguably in Case $\mathrm{E}$ the collateral restrictions facilitate transfer to the joint venture of valuable knowledge or know-how vital to the joint enterprise and presently solely in the hands of the U.S. parent. Are such restrictions necessary?

The Guide places the burden of proof on the defendants to establish both that the know-how transferred has substantial value, and that the restraint is no greater in scope or duration than is "necessary to prevent frustration" of the underlying joint venture and licensing arrangement. ${ }^{23}$ The Guide suggests that the reasonableness of the duration of a technology sharing restriction may be measured by reference to what is called "the reverse engineering period"- the length of time it would take the restricted firm to develop the know-how on its own. ${ }^{24}$ Since in Case $\mathrm{E}$ the restriction is permanent, it clearly exceeds the reverse engineering period and is therefore excessive. Indeed, since the technology is changing rapidly, only a "short term" restriction is deemed appropriate by the Guide. ${ }^{25}$

The Department does not indicate what it means by "short term" restriction, nor for that matter by what standard one might determine whether a geographic restriction is reasonable in scope. Moreover, determination of the reverse engineering period seems fraught with difficulty in view of the

${ }^{23}$ Antitrust Guide, supra note 2, at 31.

${ }^{24}$ Id. The reverse engineering concept was apparently taken from Kewanee Oil Co. v. Bicron Corp., 416 U.S. 470 (1974), which contained merely a passing reference to the fact that trade secret law does not protect against discovery of a secret by "fair and honest means" such as reverse engineering, "that is by starting with the known product and working backward to divine the process which aided in its development and manufacture." Kewanee Oil Co. v. Bicron, supra at 476. See also Douglas E. Rosenthal, Department of Justice Antitrust Guide for International Operations on International Know-How Arrangements, remarks to ABA Section on Corporation, Banking and Business Law in New York City (Dec. 15, 1978).

${ }^{25}$ Antitrust Guide, supra note 2, at 31. 
high technical complexity and uncertainty of the concept. ${ }^{26}$ One senses, therefore, that more precise standards of scope and duration for ancillary restraints remain to be worked out. Most especially this is true of ancillary arrangements involving transfers of know-how and process patents, where important principles of antitrust law, most notably the extent to which restrictions can be placed on licensee production of unpatented end products, are themselves in a state of flux entirely apart from joint venture aspects. ${ }^{27}$ And clearly attempts to reinforce the territorial restraints, imposed on the joint venture by customer restrictions on its sales to third parties who import the end product into the United States, would raise grave questions. ${ }^{28}$

Finally, a caveat seems in order as to the Guide's suggestion that "different considerations" might apply if the joint

${ }^{26}$ It is nevertheless defended by the chief of the Antitrust Division's Foreign Commerce Section as "theoretically accessible to a factfinder through expert testimony," despite difficulties. Rosenthal, supra note 24, at 7. Compare Kirkpatrick and Mahinka, Antitrust and the International Licensing of Trade Secrets and Know-How: A Need for Guidelines, 9 LaW and Policy InT'L. Bus. 725, 743-744 (1977) (concept "generally very helpful, but . . . of limited utility in certain contexts as . . where there is no realistic possibility that the licensee could ever develop the technology transferred . . .") and Fugate, Antitrust Guide, supra note 8, at 673-674 ("a new concept . . . neither firmly rooted in logic nor of much help to businessmen because of its limited nature").

${ }^{27}$ See United States v. Studiengesellschaft Kohlr, HmbH, 1978-2 TRAde CASes (CCH) 962,291 (D.D.C. 1978) (restriction on sale of unpatented end products produced under process patent held unlawful under Sherman Act); Rosenthal, supra note 24 (analysis in Case E "arguably too permissive" in light of Studiengesellschaft, but nevertheless distinction between know-how licenses and process patent licenses remains possible). See generally, Kirkpatrick \& Mahinka, supra note 26.

${ }_{28}$ See Rosenthal, supra note 24, at 10 ("almost never to be justified under a rule of reason standard"). See also Kirkpatrick \& Mahinka, supra note 26, at 738-739 (non-territorial restrictions in know-how exchanges). 
venture were under the control of the U.S. parent with the Japanese parent having a minority rather than a jointcontrolling interest. ${ }^{29}$ While in a literal sense the statement may be correct, the possible implication that placing control in one parent radically changes the competitive analysis seems too strong. The joint venture significantly alters the competitive incentives of the parties so long as the non-controlling parent has a substantial economic interest in the joint enterprise, and the restrictive effects of collateral restrictions remain. ${ }^{30}$

Despite these uncertainties some principles do emerge from Case $E$ (construed against the background of prior law) as to unlimited term market extensions. First, when the joint venture is a market extension as to both parents (i.e., both parents are already in the joint venture's product market), a significant issue of potential competition injury is likely to be present, ${ }^{31}$ as well as collusion risk when the parents are themselves competitors. Second, when the joint venture is a market extension as to only one parent and neither parent appears capable of unilateral entry, formation of a joint venture will generally be permissible. Third, agreements restricting competition between the joint venture affiliates will be permitted only to the extent the parties can demonstrate that the restrictions are indispensable to the formation of the joint venture. Fourth, even when a competitive restriction can be justified, it must be limited in time; and in general the shorter the limitation, the better.

28 Antitrust Guide, supra note 2, at 32 .

30 See Rosenthal, supra note 24, at 11-12 (noting with specific reference to Case $\mathrm{E}$, competitive dangers when non-controlling foreign parent is significant potential entrant into U.S. market).

31 In the two parent potential entry case injury to potential competition has been recognized as a basis for antitrust liability not only under the Clayton Act but also under the Sherman Act. See United States v. National Lead, 63 F. Supp. 513 (S.D.N.Y., 1945), modified and aff'd., 332 U.S. 319 (1947); and see generally, Brodley, Joint Ventures, supra note 1, at 459-460 (Sherman Act cases collected). 


\section{VERTICAL JOINT VeNTURES}

Vertical joint ventures between large competitors or potential competitors in concentrated markets raise antitrust risks because the joint venture directly eliminates competition between the parents either in downstream sales or upstream purchases. Downstream joint ventures have long been suspect as between parents having market power since such joint ventures typically involve the marketing of the parents' output, and thus by necessity price fixing and market division. ${ }^{32}$ But the legal decisions have taken a less hostile view of the upstream joint venture, which generally involves production of some common input utilized by the parents. ${ }^{33}$ The Antitrust Guide focuses on two types of upstream joint ventures: a joint research venture involving problems of competitor collaboration and a risk-sharing joint venture involving problems of bottleneck exclusion. These are among the strongest asserted justifications for joint ventures, and thus the Guide's teaching as to when even these joint ventures run into antitrust problems can be particularly instructive.

\section{Joint Research}

Joint research activity among firms in the same industry, but operating in distinct geographic markets, is the subject of the joint venture in Case $D$. The parents of the joint venture are major producers of an end product called "X-metal," which is manufactured from X-ore. One parent is the second largest producer of X-metal in the United States and the other is one

32 See e.g., Citizens Publishing Co. v. United States, 394 U.S. 131 (1969) and United States v. Paramount Pictures, 334 U.S. 131, 150-153 (1948); see generally Brodley, Joint Ventures, supra note 1, at $456-457 ; 466-470$.

33 See United States v. Topco Associates, 405 U.S. 596 (1972); and see generally Davidow, Antitrust Foreign Policy and International Buying Cooperation, 84 Y ALE L.J. 268 (1974). 
of the largest producers in the Common Market. ${ }^{34}$ The joint venture, which is to be formed in the United Kingdom, will conduct all research for the parents aimed at discovering a method of producing the X-metal from a new and more abundant raw material source. Research success could thus have large competitive significance in both raw material and endproduct markets. Prior to formation of the joint venture the parents and several other X-metal producers were engaged in similar research, at least at a preliminary stage. No researcher, however, had developed a workable process. In forming the joint venture the parties agreed that should the joint venture succeed, the resulting process patent and know-how rights would be divided between the parents: the U.S. parent would receive an exclusive license for North America, and the Common Market parent an exclusive license for Europe and certain other foreign areas.

In analyzing Case D the Antitrust Guide recognizes no blanket immunity for research joint ventures. Indeed, the analytic approach is similar to that applied to other types of joint ventures, the issues being elimination of existing competition between the parents, unreasonable collateral restraints, and bottleneck foreclosure. ${ }^{35}$

Necessarily, the joint venture will eliminate research competition between the parents in what is clearly a competitively significant undertaking. Since the parents are large firms in concentrated markets and the number of other researchcapable and motivated firms is limited, detailed inquiry is necessary to determine whether the joint venture will be injurious to long-run competition in the X-metal industry itself.

34 Case D does not explicitly state whether the parents are actual or potential competitors as to the end product. But the facts that Xmetal is presumably heavy, that the parents are geographically distant and that their relative size in the United States and Common Market are separately described, all suggest that competition is essentially, or mainly, potential rather than actual.

${ }^{35}$ Antitrust Guide, supra note 2, at 23. The third issue is not applicable on the facts presented in Case D. 
Under the Guide's analysis this breaks down into three subsidiary questions: (1) whether research costs and risks are so high that without the joint venture the research would not be undertaken by the parents; (2) whether the joint venture is sufficiently limited in time and scope; and (3) whether other firms in the industry are sufficiently engaged in comparable research to provide "continuing competitive incentives." ${ }^{36}$

These factors are found to be satisfied in Case D, but the facts supplied are so sparse that one must conclude that either a modest showing will suffice or, more probably, that the Department has made very little commitment as to what constitutes a sufficient justification for an $R$ \& $D$ joint venture. Thus, as to the first factor (prohibitive individual research costs), both parents were in fact already engaged in preliminary research. Hence the most that could be asserted is that the parents would not have undertaken as much research in the absence of the joint venture, a fact uniquely ill-suited as a basis for a legal standard.

The second factor (limitation of time and scope) seems less troublesome since a research joint venture can, as in Case D, be limited to a specific research goal. An appropriately limited scope may at least implicitly limit the duration of the joint venture, there being no reason to continue the venture beyond the life of the specific research project. This, however, should not be left to implication; it should be made explicit.

Turning to the third factor (significant research competition from other firms), it is clear that a complete absence of research competition, such as would result from an industrywide joint venture, would be a strong presumptive reason against a joint venture. ${ }^{37}$ Assuming that some research com-

\footnotetext{
36 Id. at 25.

${ }^{37}$ In this connection the Antitrust Guide reflects the current, stringent view toward industry-wide research. In past years the Antitrust Division viewed such research more permissively if the research results were made available to the whole industry. See Fugate, Antitrust Guide, supra note 8, at 665-666.
} 
petition remains, however, it is unclear what the quantum must be in order to escape antitrust censure. The Antitrust Guide states only that "other leading U.S. and foreign firms will continue to parallel the efforts of the joint venture" and that this will provide a "competitive spur," as well as weaken any inference that the venture is "a device for restraining competitive research." ${ }^{38}$ We are given no information as to either the number or vitality of the other research efforts except that the firms involved are large (but then so were the parents who were presumable ineffective in their separate research).

Thus, it is difficult to draw from the discussion of Case D more than certain threshold conditions for a permissible joint research undertaking between large competitors or potential competitors in concentrated markets. These appear to be simply that (1) the research task is of sufficiently high cost or risk that the parents can reasonable establish that they would not have undertaken the research individually, (2) the joint venture is confined to that research task, (3) formation of the joint venture will not eliminate or preclude all competitive research in the industry, and (4) no special risk of collusive spillover between the parents is present.

In addition to the joint research venture in Case $D$, there is present a collateral agreement covering process patents and know-how discovered by the joint venture. Under this agreement the joint venture is required to assign to each parent for use within its home territory, an exclusive territorial license to process patents and know-how discovered by the joint venture. As we have seen above, the antitrust status of process patents and know-how licensing agreements is in itself a difficult and unsettled legal question. ${ }^{39}$ The fact that such agreements are contained within a joint venture context weaves a third, potentially competitive entity into the network of agreements,

\footnotetext{
38 Antitrust Guide, supra note 2, at 24.

so See, supra notes 27-28 and accompanying text, and see generally Kirkpatrick \& Mahinka, supra note 26.
} 
and focuses attention on whether the whole is more restrictive of long-run competition than is necessary. More specifically, if there is already some legal doubt as to the legality of restrictions on end-product sales by licensees of process patents and know-how, the addition of a joint venture as an additional party to the licensing arrangement cannot improve the competitive picture. Not only is the joint venture itself likely to be subject to territorial and perhaps other restraints, but management and operation of the joint enterprise is typically under the dual control of parents, who are likely themselves to be actual or potential competitors. Noting the latter possibility, the Guide expresses concern as to the risk of spillover collusion in research joint ventures and appears to call for some specific steps by the parties to assure that there is no discussion of production and marketing subjects. ${ }^{40}$

\section{Risk Sharing and Bottleneck Exclusion}

Vertical joint ventures may, in addition to reducing competition between the parties, raise the problem of bottleneck exclusion. In Case $\mathbf{M}$ several major domestic and foreign oil companies, concerned about continued access to low sulphur oil from concessions in Third World countries, form a joint venture to share the political risk of possible interruptions of their oil supply. The joint venture, to be located abroad, would assure a continued supply of low sulphur oil in the event of interruption, through back-up commitments from outside sources. Under these circumstances neither the formation of the joint venture nor collateral agreements pose significant antitrust problems. ${ }^{41}$ Formation of the joint venture is essential

40 Antitrust Guide, supra note 2, at 27. Specific reference is made to Case $C$, and precautions are suggested to avoid spillover collusion, e.g., separate personnel for joint venture "to reduce day-to-day contact." Id. at 20 . The problem is particularly acute if the parents are actual competitors as to end-product sales, in which case a corporate structure to maintain maximum separation of joint venture and parents may be advisable.

4 Antitrust Guide, supra note 2, at 58-61. 
in view of both the high risks which it serves to reduce and the limited purpose of the joint undertaking. ${ }^{42}$ Since there are also no objectionable collateral agreements, the only substantial antitrust issue is bottleneck exclusion.

A bottleneck problem arises because the three American participants in the joint venture wish to exclude another American company ("Maverick") which also operates concessions in the area. The crucial issue in resolving the legality of this exclusion is whether the joint venture supplies an essential input to Maverick, the absence of which will place it "at serious disadvantage." 43 Thus, if an assured source of low sulphur crude is essential to Maverick and no feasible substitute source is available to it on roughly comparable terms, the bottleneck rule would apply: Maverick would be entitled to access to the low sulphur crude on a non-discriminatory basis. This result is consistent with past decisions on bottleneck joint ventures, though it should be noted that the decided cases have been concerned with permanent joint ventures, as distinct from a limited term joint venture, as present here. ${ }^{44}$ But no reason appears for not applying the bottleneck rule to prevent severely damaging exclusions from limited term, as well as permanent, joint ventures.

42 This conclusion is qualified by the suggestion that since the joint venture has a limited purpose, "prudence would dictate" that the venture be given a fixed termination date to assure that it does not move into impermissible collaboration after its original purpose has expired. Antitrust Guide, supra note 2, at 58-59.

As a factual matter one may question whether in today's world the purpose and need to obtain an assured supply of oil from Third World countries will ever have a cut-off or termination time. Still it may be better practice to include a termination date, there being nothing to prevent a future extension of the joint venture's life if the parties require it.

43 Id. at 60 .

${ }^{44}$ See generally Brodley, Joint Ventures, supra note 1 , at 468-469; Antitrust Guide, supra note 2, at 58-60, nn.107-113 (citing cases). 
Admission of the excluded Maverick to the benefits of the joint venture, including membership, would be required, it appears, even if the reasons for exclusion were non-invidious. It is therefore an aggravating factor that the motives for excluding Maverick are objectionable in themselves, being based on Maverick's competitive behavior as an "unpredictable factor" and a source of supply to independent U.S. refiners. ${ }^{45}$ This, of course, makes the case for Maverick's compulsory access to the joint venture even stronger, and negates any good faith defense.

The Guide's treatment of Case M adds little to existing doctrine as to joint ventures with bottleneck properties. Perhaps of most importance is that it makes explicit the Department's view that a limited term joint venture may be exclusionary if the input is essential. Determining whether an input is essential will, however, sometimes be difficult, particularly when the shared risk is an uncertain political risk, as in Case M. This may explain the Guide's emphasis on the motives for exclusion, and suggests that when the effect of the exclusion is less than clear-cut, intent evidence may be determinative. Even when exclusion is unjustified, however, the remedy is not to dissolve the joint venture, but to require admission of the excluded party. (Of course, this will not solve the existing parties' treble damage problems covering the period of exclusion.)

\section{ConCLusion}

Focusing on three poorly illuminated areas of joint venture law, the Antitrust Guide finds scope in international transactions for lawful activity, even as among competitors having market power. Limiting somewhat the implications of the Guide's analysis is the fact that discussion is focused entirely in terms of specific and simplified hypothetical cases. Never-

45 Antitrust Guide, supra note 2, at 57. 
theless, in the three undeveloped areas of joint venture law discussed, short term consortia, one-parent market extensions and upstream vertical joint ventures, any statement of views by the Department of Justice, however guarded and qualified, adds significantly to our knowledge of enforcement policy.

Moreover, notwithstanding the limiting specificity of the discussion, certain general conclusions may be drawn. First, it appears that the indispensable precondition for the lawfulness of a joint venture between competitors with market power (in the three areas analyzed) is a showing that the venture is necessary and required in order for the parents to enter a new market or embark on a new enterprise or undertaking. Second, even in that event, the joint venture is to be allowed only such scope and term of existence as may be required to accomplish its legitimating purpose. Third, throughout its allotted life, however short, the joint venture is subject to particularized scrutiny by enforcement agencies to assure that collateral agreements and joint venture generally remain confined to the legitimated channel of activity. All of this is to say that for a joint venture in international trade between competitive or potentially competitive firms having market power a course of lawful activity will often exist, but the path must be chosen with care. This is a lesson not without instructiveness for antitrust counsel to domestic as well as international joint ventures. 